\title{
Cywilnoprawna problematyka wykorzystania gry komputerowej jako narzędzia promocji: in-game advertising oraz advergaming
}

\author{
A Set of Civil Law Issues Related to Using a Computer Game as \\ a Promotional Tool: In-game Advertising and Advergaming
}

\author{
Kamil Szpyt \\ Krakowska Akademia im. Andrzeja Frycza Modrzewskiego \\ kszpyt@afm.edu.pl | ORCID: 0000-0002-2307-8789
}

\begin{abstract}
The paper discussed two phenomena characteristic of using a computer game as a promotional tool: in-game advertising and advergaming. The starting point for the considerations comes as a presentation of the historic and social context of the phenomenon. The presentation also provides a list of indispensable definitions. The further analysis investigates an obligation to apply the advertising regulating provisions included in the most essential acts of law to computer games. The reasoning is supplemented with deliberations regarding the issue of advertising of virtual products which do not have real equivalents. In further order, the paper investigates a phenomenon of an advertiser's seeking redress on the grounds of defective advertising, as well as a possibility of the violation of the personal rights of authors of a game which stem from including an advertisement into the game or from product placement allowed by the publisher without their knowledge and consent.
\end{abstract}

Keywords: computer game, advertising, product placement, in-game advertising, advergaming 



\section{Wprowadzenie}

11 października 2018 na stronie Rządowego Centrum Legislacji opublikowano pierwotną wersję projektu ustawy o finansowym wspieraniu produkcji kulturowych gier wideo oraz o zmianie innych ustaw, zastąpioną następnie tak samo zatytułowanym projektem z 18 grudnia 2018 (dalej: Projekt), regulującym zasady ubiegania się przez niektórych przedsiębiorców o przyznanie wsparcia finansowego produkcji kulturowych gier wideo przybierającego postać ulgi w podatku dochodowym. Pod pojęciem kulturowej gry komputerowej, zgodnie z art. 2 pkt 5 Projektu, należy rozumieć grę wideo:

która wykorzystuje polski lub europejski dorobek kulturowy oraz posiada kulturotwórczy lub innowacyjny charakter, a także spełnia test kwalifikacyjny potwierdzony certyfikatem tymczasowym oraz ostatecznym i jest przeznaczona do komercyjnej dystrybucji.

Jakkolwiek łatwo się domyślić, jakie intencje przeświecały podjęciu prac nad takowymi unormowaniami, niemniej zostały one również szeroko przedstawione w samym Projekcie (art. 1 ust. 3 pkt 1-9), w którym wskazano, że celem przyznawania wsparcia finansowego produkcji kulturowych gier wideo jest m.in. poprawa warunków funkcjonowania rynku produkcji gier wideo, zwiększanie aktywności przedsiębiorców działających na tym rynku na terytorium Rzeczypospolitej Polskiej oraz wspieranie trwałego rozwoju gospodarczego państwa i jego regionów poprzez stwarzanie warunków rozwoju sektorów kreatywnych. W kontekście prowadzonych w niniejszym opracowaniu rozważań za najważniejszy należy uznać punkt ostatni omawianego przepisu, wskazujący, że dla twórców projektu równie istotny był „rozwój kultury oraz promocja wizerunku Rzeczypospolitej Polskiej oraz polskiego i europejskiego dziedzictwa kulturowego na świecie".

Niewątpliwie należy to uznać za swoisty przełom w postrzeganiu gier komputerowych przez polskiego ustawodawcę (które to pojęcie, ze względów stylistycznych, będzie stosowane jako synonimiczne dla określenia "gry wideo"; szerzej o wzajemnej relacji tych terminów zob. Szpyt, 2018, s.11-12). Jakkolwiek bowiem od pewnego już czasu rodzime instytucje państwowe podejmowały większe lub mniejsze starania mające na celu 
wspieranie polskich producentów gier, takie jak np. przyznawanie dotacji w ramach programów sektorowych (m.in. GameINN) czy organizowanie specjalistycznych konferencji (m.in. corocznej, biznesowo-prawnej "Mastering the Game”), to wydaje się, że do dziś nie doceniły w pełni potencjału, jaki tkwi w grach komputerowych jako swoistych nośnikach treści promocyjnych. Potencjału, który nawet po pobieżnym zbadaniu jawi się jako imponujący. Wystarczy odnotować, że według części raportów wartość rynku reklam w grach wideo na świecie w 2019 r. powinna osiągnąć wartość ok. 4,377 mld dol. amerykańskich, co stanowi wzrost o ok. 34 mln w porównaniu z rokiem 2018 r. (zob. Statista, 2019; por. WePC, 2018). Z tego środka promocji korzystają nie tylko międzynarodowe koncerny przy popularyzacji swoich marek (np. Nike, Pepsi, Burger King), ale również politycy, żeby wspomnieć chociażby o kampanii wyborczej byłego prezydenta USA Baracka Obamy z 2008 roku. Jego wizerunek pojawił się wówczas m.in. w takich popularnych produkcjach jak Need For Speed: Pro Street, Need For Speed: Carbon, NBA Live'08, Burnout Paradise, Nascar 09 (Ratajczak, 2018).

Jakkolwiek nawet wyrywkowa analiza statystyk wskazuje, że trend w postaci promowania własnych produktów i usług w wirtualnych światach wzmógł się przede wszystkim ostatnimi laty, rzeczywiste zainteresowanie grami komputerowymi jako nośnikami określonych treści reklamowych sięga lat 70. XX wieku. Jednakże z uwagi na niewielką moc ówczesnych konsol, jak również pierwszych komputerów osobistych, długi czas produkcji nośników, związane z tym koszty oraz ograniczoną liczbę potencjalnych odbiorców, gry wideo nie stanowiły medium łatwego do zaadaptowania. Utrudniała to również grafika o niskiej rozdzielczości, która nie tylko uniemożliwiała precyzyjne przedstawienie konkretnego znaku towarowego czy firmy, lecz nawet kształtów samego produktu trzeba się było domyślać. Gry nie stanowiły więc zbyt wdzięcznej materii do lokowania produktów, a nieskomplikowana mechanika rozgrywki w istotny sposób ograniczała zakres możliwych rozwiązań reklamowych (Gałuszka, 2018).

Z czasem, oczywiście, nastąpił w tej dziedzinie daleko idący postęp. Ponadto zmieniła się również średnia wieku samych graczy oraz ich status ekonomiczny: z niezamożnych nastolatków na - niejednokrotnie dobrze sytuowanych 30-, 40-latków; pojawił się również większy odsetek 
grających kobiet. Jeżeli dodać do tego duże zaangażowanie w rozgrywkę i ponadprzeciętne skupienie na niej uwagi (jest to medium, którego w zasadzie nie można odbierać wyłącznie „pasywnie” - zawsze wymaga ono przynajmniej minimalnego zaangażowania), co wpływa również na stopień postrzegania i zapamiętywania pojawiających się w niej elementów, otrzymujemy - w teorii - nadzwyczaj obiecujący nośnik reklamy.

Ponadto charakteryzuje się ono dziś o wiele większą dostępnością dla potencjalnych reklamodawców, przez co należy rozumieć możliwość samodzielnego wprowadzenia określonych treści do gry przez reklamodawcę, nieraz bez jednoznacznej zgody jej wydawcy czy twórców. Jako przykład należy tutaj wskazać tworzenie różnego rodzaju nieoficjalnych modów, czyli modyfikacji do gier komputerowych. Mogą one przybierać zarówno postać nowych ubrań lub uzbrojenia dla postaci (np. opatrzonego znakiem towarowym reklamodawcy), jak i całych dodatkowych questów (zadań), do których wykonania potrzebny jest np. telefon określonej marki (zob. szerzej: Szpyt, 2018, s. 82 n.). Oczywiście, podobne działania niekiedy wzbudzają liczne wątpliwości natury prawnej. Jako przykład można tutaj wskazać moda do popularnej gry komputerowej Doom noszącego tytuł Doom Fetito. Miał on na celu promowanie treści proaborcyjnych w trakcie zażartej dyskusji na temat liberalizacji przepisów aborcyjnych w Argentynie. Sprowadzał się do pojedynczej misji, w której ostatecznym przeciwnikiem (bossem) do pokonania i zabicia był... ludzki płód. Wykonanie tej misji utrudniali księża, aktywistki pro-life i... naziści (Godziński, 2018).

Nie ulega wątpliwości, że w tradycyjnej reklamie telewizyjnej podobne rozwiązanie byłoby nie do pomyślenia. Rodzi się to pytanie o legalność takowych działań. Jakkolwiek bowiem, wnioskując z orzecznictwa, w niektórych przypadkach mogą pojawić się trudności z dowiedzeniem naruszenia dóbr osobistych konkretnej jednostki w sytuacji, gdy obraźliwy przekaz kierowany był do całej grupy społecznej (np. duchowieństwa), niemniej nie można takowego stanowiska odrzucać a priori (zob. m.in. wyrok Sądu Najwyższego z 21 września 2006, I CSK 118/06, OSNC 2007, Nr 5, poz. 77; Jabczuga-Kurek, 2016, s. 67-77). Otwarta pozostaje również kwestia pociągnięcia autora do odpowiedzialności np. z tytułu popełnienia przez niego przestępstwa znieważenia uczuć religijnych (por. Budyn-Kulik, 2014, s.107). Oczywiście zawsze 
dopuszczalna jest dyskusja o swobodzie twórczości artystycznej, jednakże - zwłaszcza w kontekście twierdzeń niektórych przedstawicieli doktryny prawniczej - rodzi to pytanie o zasadność uznawania gier komputerowych za obszary objęte tzw. magicznym kręgiem, który sprawia, że wszelkie działania podejmowane w ramach ich świata przedstawionego są prawnie indyferentne (zob. szerzej: Szpyt, 2018, s. 10-108; Tseng, 2011, s. 560; Zimmer-Czekaj, 2009, s. 92). Tym bardziej że coraz częściej praktyka przeczy takowym założeniom, o czym świadczy chociażby proces wytoczony przez Lindsay Lohan producentowi gry GTA V, w którym aktorka zarzuciła mu bezpodstawne wykorzystanie w materiałach promocyjnych jej wizerunku (Kacperski, 2018).

Powyższe wątpliwości zrodziły potrzebę bliższego przyjrzenia się reklamie wykorzystywanej w ramach światów gier i jej prawnym regulacjom. W ich kontekście konieczne stało się przede wszystkim odpowiedzenie na pytanie, czy przepisy prawa powszechnie obowiązującego znajdą zastosowanie także w odniesieniu do reklamy przekazywanej za pomocą gier komputerowych, czy też w tym przypadku z jakichś względów będzie ona wyłączona spod oceny wszystkich lub też niektórych przepisów prawa. Jednocześnie, konstatując, iż większość opracowań prawnych sprowadza się przede wszystkim do podejmowania prób analizy zagadnienia reklamy $w$ grach komputerowych jedynie z punktu widzenia ewentualnego naruszenia praw odbiorców/graczy, zasadne wydało się zwrócenie szczególnej uwagi na problematykę praw twórców gier komputerowych, jak i samych wydawców w kontekście umieszczania w grach treści promocyjnych. Zarazem poza obszarem niniejszych badań pozostała prawna problematyka promowania samych gier komputerowych (np. w telewizji, radiu, internecie).

\section{In-game advertising $\mathrm{i}$ advergaming - wyjaśnienie pojęć}

W doktrynie wysunięto wiele propozycji odnośnie do potencjalnych sposobów typologizacji form reklamy wykorzystywanych w grach komputerowych (zob. m.in. Štavljanin, Cvijović, Kostić-Stanković, 2017, s.119; Edery, Mollick, 2009, s. 35; Mitręga, 2013, s. 136-137; Hofman-Kohlmeyer, 
2017, s. 71-72). Najpopularniejszy, a zarazem najprostszy z nich to podział na in-game advertising oraz advergaming.

Pierwszy z powyższych terminów można przetłumaczyć jako „reklama w grze”, co jest nieco mylące. Rzeczywiście, praktyka ta niekiedy sprowadza się do umiejscawiania w świecie gry określonych informacji o towarach lub usługach reklamodawcy w celu wpływania na kształtowanie się popytu na nie (por. różne definicje reklamy: Jaworska-Dębska, 1989, s. 21; Preussner-Zamorska, 1993, s. 55-68; Kramer, 1995, s. 151; Grzybczyk, 2012, s. 16). Może to przybierać postać np. spotu zaprezentowanego w ramach intra do samej gry czy wyświetlonego na ekranie telebimu znajdującego się w świecie gry (np. reklama Burger King w Need For Speed: Most Wanted).

Znacznie częściej jednak in-game advertising będzie sprowadzał się do lokowania produktu (product placement). Praktyka ta polega na umieszczeniu pewnego produktu (a w zasadzie jego wirtualnego odpowiednika) w świecie gry w sposób pozornie przypadkowy, tak jednak, by gracz mógł dokładnie zapoznać się z jego nazwą, wzorem czy logo. Produkt taki bywa albo wykorzystywany przez awatara (postać, którą kieruje gracz), albo wkomponowywany jako element scenerii (por. Grzybczyk, 2012, s.11; Kozłowska, 2006, s. 75). Lokowanie produktu od tradycyjnej reklamy odróżnia przede wszystkim brak bezpośredniej perswazji, jak również jego częstokroć pozytywny wpływ nie tylko na sprzedaż promowanego produktu, ale również na odbiór samej gry, która dzięki „rzeczywistym” elementom nabiera atrakcyjności, a jej świat - wiarygodności (np. trudno grać w FIFA na stadionie o całkowicie „nagich”, pozbawionych reklam bandach) (zob. tamże, 2012, s. 22). Z rzeczoną formą promocji można spotkać się m.in. w następujących tytułach:

- Tom Clancy's Splinter Cell: Chaos Theory - Axe, Nokia, AMD;

- Need For Speed: Most Wanted - Castrol Syntec;

- Metal Gear Solid: Peace Walker - Mountain Dew, Pepsi, Doritos, Axe;

- Second Life - Toyota.

Niekiedy produkt stanowi tak istotny element gry, że jego wykorzystanie jest warunkiem sine qua non ukończenia rozgrywki. Jako przykład można tutaj wskazać Tom Clancy's Splinter Cell: Pandora Tomorrow, w którym główny bohater - agent Sam Fisher - musi wykorzystać telefon marki Sony Ericsson do wykonania terroryście zdjęcia, które następnie jest przesyłane do centrali w celu dokonania identyfikacji (Czubkowska, 2018). 
In-game advertising może mieć charakter statyczny lub dynamiczny (zob. Ghirvu, s. 115-116; Hałuszczak, 2013, s. 258). Pierwsze z tych rozwiązań sprowadza się do umieszczenia w grze elementów promocyjnych na stałe, drugie pozwala na ich zmienianie i prezentowanie coraz to nowych treści (np. 2005 SWAT 4 - wersja 1.1 tej gry zawiera dynamiczne reklamy dostarczane przez Massive Incorporated). Przy czym ich charakter może być uzależniony od określonych zachowań gracza w grze.

Mając na uwadze powyższe, konkretne działania podejmowane w ramach in-game advertising należy każdorazowo indywidualnie przyporządkowywać albo do klasycznej reklamy, albo do lokowania produktu. Jakiekolwiek próby klasyfikacji a priori, bez dokładnego zbadania konkretnego przypadku, skazane są na niepowodzenie. Jednocześnie, ze względów stylistycznych, gdy w dalszej części opracowania mowa będzie o reklamowaniu produktu w grze komputerowej, dotyczyć to będzie również jego lokowania, chyba że co innego zostanie zastrzeżone. Analogicznie sytuacja będzie miała miejsce w przypadku terminów „reklamodawca” i „podmiot zlecający lokowanie produktu”.

Przechodząc do advergamingu, należy wskazać, że pojęcie to stanowi połączenie dwóch terminów: game/gaming (gra/granie) i advertising/ advertisement (reklama). Jak trafnie zdefiniował wspomniane zjawisko Damian Gałuszka:

to praktyka tworzenia od podstaw gier reklamowych (ang. advergames), których głównym - i niekiedy jedynym - celem jest promowanie i zwracanie uwagi na konkretny produkt, markę, usługę czy ideę.

Pierwszym przypadkiem advergamingu była produkcja oparta na klasycznej Space Invaders i nosiła nazwę Pepsi Invaders. Sprowadzała się do niszczenia pojawiających się kolejnymi falami kosmitów. Sam mechanizm gry został powielony przy jednoczesnym zamienieniu statków kosmicznych na układające się w liniach litery P-E-P-S-I, które należało zestrzelić. Wspomniana gra została zapakowana w czarne pudełka i podarowana pracownikom Coca-Cola Company. Inne analogiczne przypadki to choćby PepsiMan, w której należy uciekać przed wielką puszką i gasić pragnienie wiadomym napojem, oraz King Games, gdzie jednym z naszych zadań jest wyskakiwanie na niczego nie podejrzewających przechodniów i oferowanie im produktów Burger Kinga (Gałuszka, 2018; Czubkowska, 2018; Radzewicz, 2018). 


\section{Przepisy regulujące problematykę reklamy w Polsce}

W Polsce brak jednego aktu prawnego regulującego kompleksowo wszystkie zagadnienia związane $\mathrm{z}$ tworzeniem i wykorzystaniem reklamy (Makowiec, 2014, s.14). Dotyczące tego przepisy zostały rozsiane po różnych ustawach, z których najważniejsze to:ustawa o radiofonii i telewizji z 29 grudnia 1992 (t.j. Dz.U. 2019.361 z późn. zm.) (dalej: u.r.t.);

- ustawa Prawo prasowe z 26 stycznia 1984 (t.j. Dz.U. 2018.1914 z późn. zm.) (dalej: pr. pras.);

- ustawa o zwalczaniu nieuczciwej konkurencji z 16 kwietnia $1993 \mathrm{r}$. (t.j. Dz.U. 2019.1010 z późn. zm.) (dalej: u.z.n.k.);

- ustawa o ochronie zdrowia przed następstwami używania tytoniu i wyrobów tytoniowych z 9 listopada 1995 (t.j. Dz.U. 2019.2182);

- ustawa o wychowaniu w trzeźwości i przeciwdziałaniu alkoholizmowi z 26 października 1982 (t.j. Dz.U.2018.2137 z późn. zm.) (dalej: u.w.t.);

- ustawa Prawo farmaceutyczne z 6 września 2001 (t.j. Dz.U. 2019.499 z późn. zm.);

- ustawa o grach hazardowych z 19 listopada 2009 (t.j. Dz.U. 2019.847 z późn. zm.).

Niektórzy autorzy dodatkowo wskazują wybrane przepisy Konstytucji Rzeczypospolitej Polskiej z 2 kwietnia 1997 (Dz.U. 78.483 z późn. zm.), w szczególności zaś art. 76 i art. 64 ust. 1, 2 i 3 (tak m.in. Makowiec, 2014, s. 14), jako podstawy działalności reklamowej tudzież jej ograniczania. Niewątpliwie stanowisko to należy uznać za trafne, niemniej stopień ogólności jest na tyle duży, że ich kompleksowe analizowanie dalece wykraczałoby poza ramy niniejszego opracowania, nadając mu jednocześnie nadmiernie teoretyczny charakter.

Pierwsze i najważniejsze pytanie, na które należy odpowiedzieć, to czy wszystkie powyższe akty prawne mogą mieć zastosowanie do gier komputerowych. Wątpliwości rodzą się zwłaszcza w kontekście u.r.t. oraz pr. pras.

W przypadku pierwszej z rzeczonych ustaw, zawarty w niej art. 1a ust. 1 wskazuje, że stosuje się ją „do dostawców usług medialnych ustanowionych na terytorium Rzeczypospolitej Polskiej. 
Usługą medialną jest usługa w postaci programu albo audiowizualnej usługi medialnej na żądanie, za którą odpowiedzialność redakcyjną ponosi jej dostawca i której podstawowym celem jest dostarczanie poprzez sieci telekomunikacyjne ogółowi odbiorców audycji, w celach informacyjnych, rozrywkowych lub edukacyjnych; usługą medialną jest także przekaz handlowy; audycją jest ciąg ruchomych obrazów z dźwiękiem lub bez niego (audycja audiowizualna) albo ciąg dźwięków (audycja radiowa), stanowiący, ze względu na treść, formę, przeznaczenie lub autorstwo, odrębną całość w stworzonym przez dostawcę usługi medialnej programie lub katalogu audycji publicznie udostępnianych w ramach audiowizualnej usługi medialnej na żądanie, zwanym dalej „katalogiem”.

Programem jest uporządkowany zestaw audycji, przekazów handlowych lub innych przekazów, rozpowszechniany w całości, w sposób umożliwiający jednoczesny odbiór przez odbiorców w ustalonym przez nadawcę układzie.

Współczesne gry komputerowe rzeczywiście zazwyczaj składają się m.in. z utworów audiowizualnych w postaci tzw. cutscenek (przerywników filmowych odgrywanych na określonych etapach rozgrywki) lub intra, co nie oznacza, że powinny być z nimi utożsamiane. Oprócz nich w skład gier wchodzi szereg innych elementów programowych (w szczególności naczelny program komputerowy, tj. silnik), wizualnych (zdjęcia, obecne w grze teksty) czy audialnych (efekty dźwiękowe, kompozycje muzyczne), które dopiero łącznie stanowią pewną całość - grę komputerową (zob. Szpyt, 2018, s. 5). Tak więc zawarty w grze utwór czy utwory audiowizualne z pewnością nie stanowią „odrębnej całości” wymaganej dla uznania zaistnienia audycji. Trudno też mówić o wymaganym dla programu ,jednoczesnym odbiorze w ustalonym przez nadawcę składzie” (każdy gracz włącza grę w dogodnym dla siebie czasie i gra w nią we własnym tempie, często przerywając lub - jeżeli jest taka możliwość - zmieniając kolejność zadań, ewentualnie pomijając niektóre z nich). Stanowisko, zgodnie z którym u.r.t. nie ma zastosowania do reklam i lokowania produktu w grach komputerowych, jakie w żadnym razie nie mogą być uznane za audiowizualne usługi medialne, jest powszechnie akceptowane w doktrynie (zob. m.in. Hałuszczak, 2013, s. 260; Bagieńska-Masiota, 2014, s. 182, 191; Grzybczyk, 2014, s. 58).

Należy również odrzucić dopuszczalność zastosowania - do gier komputerowych -przepisów pr. pras., które przeznaczone są do regulowania działalności prasowej. Same gry wideo nie mogą być uznane za prasę, 
m.in. ze względu na niespełnienie wymienianego w ustawie wymogu periodyczności i niejednorodności przekazu (art. 7 ust. 2 pkt 1 pr. pras.).

Natomiast przepisy wszystkich pozostałych wymienionych wyżej ustaw znajdą zastosowanie zarówno w przypadku in-game advertisingu, jak i advergamingu. Przy czym nie zawsze będzie to proste i jednoznaczne. Przykładowo, istotne wątpliwości mogą się zrodzić w sytuacji, gdy działania mające miejsce $w$ ramach in-game advertisingu będą dotyczyły produktów mających jedynie swój wirtualny odpowiednik. Kroki takie mogłyby zostać podjęte np. przez debiutującego producenta wysokoprocentowych napojów alkoholowych, który chce najpierw spopularyzować swój nowy produkt wśród potencjalnej grupy nabywców, np. graczy Second Life. W związku z tym tworzy wirtualny odpowiednik butelki wódki/whisky/calvadosu, rejestrując dla danej marki znak towarowy, ale początkowo jedynie dla towarów takich jak programy komputerowe, gry komputerowe itp. (m.in. klasa 9, 28 i 42 klasyfikacji nicejskiej), nie zaś alkohole wysokoprocentowe (klasa 33 klasyfikacji nicejskiej). Po czym przystępuje do jego intensywnej promocji i dopiero kiedy produkt jest rozpoznawalny, wprowadza jego realny odpowiednik na rynek, jednocześnie wycofując się z promocji w świecie gry. Odpowiedź na wspomniane pytanie tylko z pozoru wydaje się prosta. Gdyby zagadnienie dotyczyło „realnego” alkoholu (np. pojawiających się onegdaj w grze Pole Position banerów ze znakiem towarowym marki Martini [Radzewicz, 2018]), obowiązek dostosowania się do określonych obostrzeń byłby oczywisty. Natomiast zgodnie z art. 2 ust. 1 pkt 3 u.w.t. reklama napojów alkoholowych to:

ubliczne rozpowszechnianie znaków towarowych napojów alkoholowych lub symboli graficznych z nimi związanych, a także nazw i symboli graficznych przedsiębiorców produkujących napoje alkoholowe, nieróżniących się od nazw i symboli graficznych napojów alkoholowych, służące popularyzowaniu znaków towarowych napojów alkoholowych; za reklamę nie uważa się informacji używanych do celów handlowych pomiędzy przedsiębiorcami zajmującymi się produkcją, obrotem hurtowym i handlem napojami alkoholowymi.

Mając na uwadze powyższe, wydaje się, że dopóki producent nie zarejestruje swojego znaku towarowego także dla napojów alkoholowych, ograniczenia zawarte w u.w.t. nie będą miały zastosowania do jego akcji promocyjnych w świecie gry. Oczywiście, można zastanowić się nad 
podjęciem prób zakwalifikowania takowej promocji np. jako reklamy sprzecznej z dobrymi obyczajami, a więc stanowiącej czyn nieuczciwej konkurencji (art. 16 ust. 1 pkt 1 u.z.n.k.), aczkolwiek niewątpliwie budziłoby to istotne zastrzeżenia i każdy potencjalny przypadek należy rozpatrywać indywidualnie.

Jeszcze dalej idące wątpliwości mogą wystąpić w sytuacji, gdy sam status prawny reklamowanego dobra jest niejasny, nie mówiąc już o stosowaniu przepisów dotyczących jego reklamowania. Jako najlepszy przykład posłużą tutaj wzbudzające ostatnimi czasy wiele kontrowersji oraz ponadnarodową debatę loot boxy, czyli skrzynki zawierające losowe wirtualne dobra (Wikipedia, 2018). W ustawodawstwach niektórych krajów (np. Belgia, Korea Południowa) podobna praktyka zaczyna być obecnie kwalifikowana jako hazard (zob. Witczak, 2018, s. 5). Na gruncie rodzimego prawodawstwa brak jednak obecnie podstaw do wysuwania podobnych wniosków. W świetle obowiązującego prawa nie będą zatem miały - wobec loot boxów - zastosowania ewentualne legislacyjne ograniczenia reklamy gier hazardowych. Niemniej, w niedalekiej przyszłości, sytuacja ta może ulec istotnej zmianie.

\section{Odpowiedzialność za szkody spowodowane stworzeniem wadliwej reklamy}

Jak wynika z ustaleń poczynionych w poprzednim podrozdziale, w przeważającej większości przypadków do treści promocyjnych zawartych w grach komputerowych będą miały zastosowanie przepisy prawa powszechnie obowiązującego. Pomimo faktu, że w takowych sytuacjach mogą wystąpić pewne wątpliwości w zakresie ich prawnej oceny wynikające ze specyficznego charakteru samych gier, zasady wdrażania owych przepisów należy uznać za $\mathrm{w}$ miarę klarowne. Przeważnie z równie oczywistą sytuacją będziemy mieli do czynienia, gdy negatywna ocena reklamy wynika z jej niezgodności z treścią konkretnej umowy zawartej pomiędzy wydawcą gry komputerowej a reklamodawcą. W takich przypadkach zagadnienie odpowiedzialności i jej ewentualnego rozłożenia pomiędzy ww. stronami jawi się jako niebudzące większych, charakterystycznych jedynie dla tego medium, wątpliwości, a przy jej stwierdzaniu 
należy posiłkować się ustaleniami doktryny i orzecznictwa dokonanymi w zakresie utworów audiowizualnych i reklamy internetowej (w szczególności w przypadku dynamicznego in-game advertisingu, gdzie może występować jeszcze pośrednik - wyspecjalizowany podmiot zajmujący się wyszukiwaniem reklamodawców i przesyłaniem reklam do gry lub agencja reklamowa) (zob. m.in. Sroga, 2014, s. 27; Frankowski, 2006, s. 1-23; z kolei o odpowiedzialności cywilnej agencji reklamowej zob. szerzej: Księżak, 2012, s. 729-741).

Natomiast interesującą kwestią, dotychczas nie poruszaną szerzej w prawniczej doktrynie, jest ewentualna możliwość wystąpienia przez reklamodawcę z roszczeniami przeciwko wydawcy gry z tytułu takiego zaimplementowania promowanego produktu do jej świata, które zamiast zachęcać, raczej zniechęca do jego zakupu. Jako przykład podobnej sytuacji należy wskazać przypadek baterii Energizer w grze Alan Wake, które były wykorzystywane do zasilania stosowanej w rozgrywce latarki (bardzo istotnej, gdyż jej światło osłabiało oponentów i w zasadzie bez jej użycia nie udawało się ukończyć gry). Niestety, baterie te... trzeba bardzo często wymieniać. Może to rodzić u gracza przekonanie (nawet podświadome), że jest to najwidoczniej produkt lichej jakości, o nadzwyczaj krótkiej żywotności (Radzewicz, 2018). Poszukując podstawy dla ewentualnych roszczeń reklamodawcy w takiej sytuacji, należałoby sięgnąć do art. 471 ustawy z 23 kwietnia 1964 Kodeks cywilny (t.j. Dz.U.2019.1145 z późn. zm.) (dalej: k.c.). Zgodnie z jego treścią:

dłużnik obowiązany jest do naprawienia szkody wynikłej z niewykonania lub nienależytego wykonania zobowiązania, chyba że niewykonanie lub nienależyte wykonanie jest następstwem okoliczności, za które dłużnik odpowiedzialności nie ponosi.

Na podstawie powyższego przepisu reklamodawca mógłby teoretycznie dochodzić od wydawcy stosownego odszkodowania, aczkolwiek jego wysokość i sama dopuszczalność takiego powództwa uzależniona byłaby od zaistnienia szeregu czynników, w tym przede wszystkim:

- niewykonania lub nienależytego wykonania umowy;

- wystąpienia szkody po stronie reklamodawcy - na podstawie omawianego przepisu można dochodzić jedynie odszkodowania z tytułu szkody majątkowej, nie zaś zadośćuczynienia związanego z krzywdą (szkodą niemajątkową) (zob. m.in. Nesterowicz, 2007, 
s. 30-31; Zelek, 2015, s. 277-278; Siedlecki, 2014, s. 42); tym samym po stronie reklamodawcy musiałaby wystąipić realna strata lub utrata korzyści (np. z powodu spadku liczby sprzedawanych baterii), którą on musiałby następnie wykazać;

- wystąpienia związku przyczynowego pomiędzy szkodą a działaniem wydawcy - i tutaj znowu reklamodawca musiałby udowodnić, że wspomniane straty nie są skutkiem np. nieprzemyślanych posunięć biznesowych, ogólnej złej sytuacji gospodarczej w kraju itp., tylko powstały one właśnie na skutek wadliwego advergamingu lub in-game adverstisingu;braku ponoszenia przez wydawcę odpowiedzialności za okoliczności, których następstwem stało się niewykonanie lub nienależyte wykonanie umowy - jako sztandarowy przykład można tutaj podać sytuację, w której wadliwa reklama była skutkiem dokładnego dostosowania się do wymogów reklamodawcy;

- braku ograniczenia odpowiedzialności wydawcy na podstawie art. 473 ust. 1 k.c. w stopniu uniemożliwiającym dochodzenie od niego odszkodowania przez reklamodawcę. Wskazana liczba przesłanek, które musiałyby zostać spełnione, aby reklamodawca mógł skutecznie ubiegać się o odszkodowanie, jest na tyle duża, że w przeważającej większości przypadków podobne roszczenia należy uznać za możliwe jedynie teoretycznie - aczkolwiek ewentualności takiej, co do zasady, odrzucić nie sposób.

\section{Reklama a naruszenie autorskich praw osobistych twórców gry komputerowej}

Oprócz wydawców gier oraz samych graczy istnieje również trzecia grupa podmiotów, których prawa mogą zostać naruszone na skutek wprowadzenia do gry komputerowej treści promocyjnych - są to jej twórcy. W szczególności mowa tutaj o przysługujących im autorskich prawach osobistych. Nie budzi bowiem wątpliwości, że gry komputerowe w przeważającej części będą stanowiły utwory w rozumieniu art. 1 ust. 1 ustawy o prawie autorskim i prawach pokrewnych z 4 lutego 1994 (t.j. Dz.U. 2018.1191 z późn. zm.) (dalej: pr. aut.) (zob. m.in. Flisak, 2008, 
s. 95; Matusiak, 2013, s. 310; Wojciechowska, 1999, s. 66-68; Ślęzak, 2006, s. 191; Bilicz, 2013, s. 197).

Analizując wskazaną kwestię, należy pamiętać przede wszystkim, że współczesne gry ( $\mathrm{z}$ drobnymi wyjątkami w postaci niektórych indie games - gier niezależnych), to utwory współautorskie, przy których kreowaniu zaangażowane są całe zespoły ludzi: grafików, scenarzystów, programistów itp. O ile w przypadku takich utworów autorskie prawa majątkowe najczęściej będą w całości skupione w rękach wydawcy gry (por. art. 15 pr. aut.), o tyle autorskie prawa osobiste mają charakter niezbywalny i nie podlegają zrzeczeniu (art. $16 \mathrm{pr}$. aut.). W rezultacie te ostatnie zawsze będą przysługiwały twórcom. Wśród owych praw można wymienić m.in. prawo dotyczące nienaruszalności treści i formy utworu oraz jego rzetelnego wykorzystania (art. 16 pkt 3 pr. aut.). Pozwala ono przede wszystkim autorom czy współautorom utworu na decydowanie o jego ostatecznym kształcie i elementach, które wchodzą w jego skład. Jako pozbawioną znaczenia należy tutaj potraktować okoliczność, że gry komputerowe mają w przeważającej części charakter komercyjny, a nie ściśle artystyczny. Pr. aut. nie różnicuje ochrony utworu w zależności od celu, w jakim ów utwór jest kreowany, lub sposobu jego wykorzystania. Przy czym najbardziej jaskrawe naruszenia występowałyby najprawdopodobniej w przypadku niewielkich indie games, na którymi pracuje ledwie kilka osób, przenoszących swoje autorskie prawa majątkowe na wydawcę/dewelopera, który czuwa nad ostatecznym rezultatem. Można sobie wyobrazić sytuację, w której ów wydawca/deweloper bez wiedzy twórców, w momencie, gdy dzieło jest już gotowe, na skutek umowy zawartej z reklamodawcą zleca podmiotowi trzeciemu (innemu twórcy) ulokowanie w grze produktu pierwotnie w niej nieprzewidzianego lub wmontowanie przerywnika reklamowego. I to w sytuacji, gdy prace pierwotnych autorów nad grą zostały już zakończone i nie mają oni możliwości dalszej ingerencji. Ewentualnie dokonanie podobnych przeróbek wydawca mógłby zlecić części twórców, nie informując o tym pozostałych. Biorąc pod uwagę, że wydawca w analizowanym stanie faktycznym nie uzyskał zgody wszystkich autorów, a zainicjowane zmiany nie zostały spowodowane oczywistą koniecznością, w sytuacji, gdy twórca nie miałby słusznej podstawy im się sprzeciwić (tj. nie została wypełniona żadna z dyspozycji art. 49 ust. 2 zd. 1 pr. aut.), opisane działania 
najczęściej należałoby zakwalifikować jako naruszające autorskie prawa osobiste współtwórców (zob. szerzej: Barta, Markiewicz, 2016, s. 140 n.; por. też uwagi odnośnie do utworów audiowizualnych: Grzybczyk, 2012, s. 139-143).

Tym samym będą one rodzić po ich stronie prawo do wystąpienia przeciwko niemu z roszczeniami, o których mowa w art. 78 ust. 1 pr. aut. W ich skład wchodzi m.in. żądanie dopełnienia czynności niezbędnych, aby usunąć skutki naruszeń (np. wydanie gry komputerowej w jej pierwotnej wersji lub wydanie specjalnej aktualizacji/modyfikacji odnoszącej taki sam skutek, tzw. patcha) oraz wypłaty zadośćuczynienia (pod warunkiem, że naruszenie było zawinione). Jak łatwo się domyślić, występowanie podobnych naruszeń będzie raczej domeną in-game advertisingu niż advergamingu, gdyż w tym drugim przypadku twórcy z założenia powinni być przygotowani, że ich dzieło zostanie wykorzystane w celach reklamowych. Nie należy jednak wykluczać a priori zaistnienia takich ingerencji, które mogłyby zostać zakwalifikowane jako naruszenie autorskich praw osobistych.

Chcąc uniknąć wymienionych utrudnień, wydawca powinien zawczasu uregulować $\mathrm{w}$ umowie $\mathrm{z}$ twórcami zagadnienie wszystkich potencjalnych modyfikacji gry, w tym reklamowania/lokowania produktu, i uzyskać w tym zakresie stosowne zgody. Otwartą kwestią pozostaje również dodatkowe zobowiązanie twórców do niewykonywania autorskich praw osobistych i upoważnienie do czynienia tego $\mathrm{w}$ ich imieniu przez wydawcę (aczkolwiek obecnie część judykatury nieprzychylnie spogląda na podobne zastrzeżenia umowne, zarzucając ich twórcom m.in. dążenie do obejścia prawa).

\section{Podsumowanie}

Podsumowując poczynione w niniejszym opracowaniu wywody, należy przede wszystkim wskazać na ogólną konkluzję, zgodnie z którą - co do zasady - w przypadku in-game advertisingu i advergamingu znajdzie zastosowanie większość aktów prawnych regulujących reklamę w innych środkach przekazu. Wyjątek stanowią tutaj przepisy dotyczące stricte radiofonii i telewizji oraz prasy. Zarazem w przypadku światów gier 
mogą wystąpić problemy, z którymi judykatura i doktryna dotychczas nie musiały się mierzyć w kontekście innych mediów, jak np. promowanie wirtualnego alkoholu. Zasadniczo nie rodzi to jednak potrzeby wprowadzania nowych regulacji, przeznaczonych wyłącznie dla gier komputerowych. Obecne unormowania wydają się w większości wystarczające, aczkolwiek przy ich wykładni należy zawsze mieć na względzie specyficzny charakter nowego medium, jakim jest gra komputerowa. Tym bardziej że weryfikacja legalności działań wydawcy i reklamodawcy w zasadzie każdorazowo będzie wymagała głębszej analizy nie tylko zawartej przez nich umowy, ale również m.in. umów łączących wydawcę z twórcami. Sytuacja ta stanowi jasny sygnał dla wydawców i reklamodawców, by poświęcali należytą uwagę konstruowaniu zawieranych przez siebie umów tak, aby uchronić się od ewentualnych przyszłych sporów i wiążącej się z tym odpowiedzialność z tytułu wadliwej reklamy tudzież naruszenia dóbr osobistych twórców gry. Jednocześnie nie budzi wątpliwości, iż problematyka ta już na obecnym etapie wymaga większego zainteresowania przedstawicieli doktryny, zwłaszcza że praktyka wykorzystywania gier komputerowych jako narzędzi promocji będzie niewątpliwie z jednej strony ewoluować, a z drugiej - zyskiwać na popularności.

\section{Literatura}

Bagieńska-Masiota, A. (2014). Product placement na tle innych przekazów handlowych. Prawna regulacja w ustawie o radiofonii i telewizji. Środkowoeuropejskie Studia Polityczne, 2(2), 173-192.

Barta, J., Markiewicz, R. (2016). Prawo autorskie. Warszawa: Wolters Kluwer. Bilicz, B. (2013). Wirtualny świat jako utwór samoistny. Twórcze wykorzystanie elementów gier komputerowych. Machinima. W: K. Grzybczyk (red.), Prawo w wirtualnych światach (s. 195-212), Warszawa: Difin.

Budyn-Kulik, M. (2014). Znieważenie uczuć religijnych - analiza dogmatyczna i praktyka ścigania. Prawo w Działaniu, 8(19), 100-137.

Czubkowska, S. (22 stycznia 2011). Od reklam w grach nikt nie ucieknie. Online: <http://biznes.gazetaprawna.pl/artykuly/480338,od-reklam-w-grach-komputerowych-nikt-nie-ucieknie.html>. Data dostępu: 31 października 2018. 
Edery, D., Mollick, E. (2009). Changing the Game. New Jersey: Pearson Education.

Flisak, D. (2008). Utwór multimedialny w prawie autorskim. Warszawa: Wolters Kluwer.

Frankowski, P. (2006). Prawne aspekty reklamy w sieci. CBKE e-biuletyn, 1, 1-23.

Gałuszka, D. (2016). Nowy wymiar reklamy - in-game advertising oraz advergaming. Kultura i Historia, 16(29). Online: <http://www.kulturaihistoria.umcs.lublin.pl/archives/5726>. Data dostępu: 1 grudnia 2018.

Ghirvu, A. (2012). In-game advertising: advantages and limitations for advertisers, The USV Annals of Economics and Public Administration, 12(1), 114-119.

Grzybczyk, K. (2012). Lokowanie produktu. Zagadnienia prawne. Warszawa: Wolters Kluwer.

Grzybczyk, K. (2014). Reklama i lokowanie produktu w grach komputerowych. Wrocławskie Studia Sądowe, 3(4), 53-75.

Godziński, B. (5 sierpnia 2018). Proaborcyjny manifest w grze komputerowej. Finałowym bossem jest... płód człowieka. Online: <http:// natemat.pl/245241,doom-fetito-proaborcyjny-mod-do-gry-w-ktorym-bossem-jest-plod>. Data dostępu: 1 grudnia 2018.

Hałuszczak, M. (2013). Product placement w grach komputerowych. W: K. Grzybczyk (red.), Prawo w wirtualnych swiatach (s. 257-285). Warszawa: Difin.

Jabczuga-Kurek, M. (2016). Legitymacja czynna członka zbiorowości w nietypowych sprawach o ochronę czci i dobrego imienia. W: B. Jelonek-Jarco, R. Kos, J. Zawadzka (red.), Usus Magister est Optimus. Rozprawy prawnicze ofiarowane Profesorowi Andrzejowi Kubasowi (s. 67-77). Warszawa: C. H. Beck.Loot box. Wikipedia. Online: <http://pl.wikipedia. org/wiki/Loot_box>. Data dostępu: 15 grudnia 2018.

Hofman-Kohlmeyer, M. (2017). Komunikacja marketingowa w grach komputerowych - współczesne kierunki badań, Studia Ekonomiczne. Zeszyty Naukowe Uniwersytetu Ekonomicznego w Katowicach, 328, 70-82.

Kacperski, K. (3 kwietnia 2018). Lindsay Lohan przegrała kolejny proces sądowy wytoczony twórcom „GTA V”. Online: <http://www.antyradio. pl/Technologia/Gry/Lindsay-Lohan-przegrala-kolejny-proces-sadowy-wytoczony-tworcom-GTA-V-21537>. Data dostępu: 7 listopada 2018.

Kozłowska, A. (2006). Reklama, socjotechnika oddziaływania. Warszawa: Szkoła Główna Handlowa - Oficyna Wydawnicza. 
Księżak, P. (2012). Odpowiedzialność cywilna agencji reklamowej. W: M. Namysłowska (red.), Reklama. Aspekty prawne (s. 729-742), Warszawa: Wolters Kluwer.

Makowiec, A. (2014). Prawe aspekty reklamy w sieci - zagadnienia wybrane. Kultura - Media - Teologia, 5(18), 9-28.

Matusiak, I. (2013). Gra komputerowa jako przedmiot prawa autorskiego. Warszawa: Wolters Kluwer.

Mitręga, M. (2013), Advergaming jako rozwijająca się forma komunikacji marketingowej. Studia Ekonomiczne, 140, 133-143.

Nesterowicz, M. (2007). Zadośćuczynienie pieniężne ex contractu i przy zbiegu z odpowiedzialnością ex delicto, Państwo i Prawo, 62(1), 20-31.

Radzewicz, S. (30 sierpnia 2013). Lokowanie produktu w grach... w dobrym, złym i nijakim stylu. Online: <http://www.spidersweb.pl/2013/o8/product-placement-w-grach.html>. Data dostępu: 1 grudnia 2018.

Siedlecki, G. (2014). Zadośćuczynienie za zmarnowany urlop. Studenckie Zeszyty Naukowe, 24, 39-45.

Sroga, A. (2014). Kto ponosi odpowiedzialność za treść reklamy?, Radca Prawny, 154, 27.

Statista (2019). Value of the video games advertising market worldwide from 2011 to 2020 (in million U. S. Dollars). Online: <http://www.statista.com/statistics/558502/value-video-games-advertising-market-global>. Data dostępu: 15 grudnia 2018.

Štavljanin, V., Cvijović, J., Kostić-Stanković, M. (2017). Research of indirect advertising in video game industry, Industrija, 45(4), 113-132.

Szpyt, K. (2018). Obrót dobrami wirtualnymi w grach komputerowych. Studium cywilnoprawne. Warszawa: C. H. Beck.

Ślęzak, P. (2006). Pola eksploatacji utworów audiowizualnych, BydgoszczKatowice: Oficyna Wydawnicza „Branta”.

Tseng, Y. S. (2011). Governing Virtual Worlds: Interration 2.0, Washington University Journal of Law \& Policy, 35(1).

WePC (2018). 2018 Video Game Industry Statistics, Trends \& Data. Online: <https://www.wepc.com/news/video-game-statistics/>. Data dostępu: 15 grudnia 2018.

Witczak, M. (2018). List otwarty do Ministerstwa Finansów, CD-Action, 23(13), 5. Online: <http://www.cdaction.pl/news-55047/list-otwarty-do-ministerstwa-finansow.html>. Data dostępu: 15 grudnia 2019. 
Wojciechowska, A. (1999). Autorskie prawa osobiste twórców dzieł audiowizualnych. Zeszyty Naukowe Uniwersytetu Jagiellońskiego. Prace z Wynalazczości i Ochrony Własności Intelektualnej, 72.

Zelek, M. (2015). Umowa o rejestrację domeny internetowej. Warszawa: C. H. Beck.

Zimmer-Czekaj, J. (2009). Prawo własności intelektualnej w wirtualnych światach. Zeszyty Naukowe Uniwersytetu Jagiellońskiego. Prace z Wynalazczości i Ochrony Własności Intelektualne, 105.

\section{Orzecznictwo}

Wyrok Sądu Najwyższego z 21 września 2006, I CSK 118/o6, OSNC 2007, Nr 5, poz. 77.

\section{Akty prawne}

Konstytucji Rzeczypospolitej Polskiej z 2 kwietnia 1997 (Dz.U. 78.483 z późn. $\mathrm{zm}$.).

Ustawa z 23 kwietnia 1964 Kodeks cywilny (t.j. Dz.U. 2019.1145 z późn. zm.). Ustawa o wychowaniu w trzeźwości i przeciwdziałaniu alkoholizmowi z 26 października 1982. (t.j. Dz.U.2018.2137 z późn. zm.).

Ustawa Prawo prasowe z 26 stycznia 1984 (t.j. Dz.U.2018.1914 z późn. zm.).

Ustawa o radiofonii i telewizji z dnia 29 grudnia 1992 (t.j. Dz.U. 2019.361 z późn. zm.).

Ustawa o zwalczaniu nieuczciwej konkurencji z 16 kwietnia 1993 (t.j. Dz.U. 2019.1010 z późn. zm.).

Ustawa o prawie autorskim i prawach pokrewnych z 4 lutego 1994 (Dz.U. 2018.1191 t.j. z późn. zm.).

Ustawa o ochronie zdrowia przed następstwami używania tytoniu i wyrobów tytoniowych z 9 listopada 1995 (t.j. Dz.U. 2019.2182).

Ustawa Prawo farmaceutyczne z 6 września 2001 (t.j. Dz.U. 2019.499 z późn. $\mathrm{zm}$.).

Ustawa o grach hazardowych z 19 listopada 2009 (t.j. Dz.U. 2019.847 z późn. $\mathrm{zm}$.).

Projekt z 18.12.2018 ustawy o finansowym wspieraniu produkcji kulturowych gier wideo oraz o zmianie innych ustaw. Online: <http://legislacja.rcl.gov.pl/projekt/12316950/katalog/12540364\#12540364>. Data dostępu: 28 czerwca 2019. 


\title{
Cywilnoprawna problematyka wykorzystania gry kompute- rowej jako narzędzia promocji: in-game advertising oraz advergaming
}

\begin{abstract}
Abstrakt: W artykule omówiono dwa zjawiska charakterystyczne dla wykorzystania gry komputerowej jako narzędzia promocji: in-game advertising i advergaming. Rozpoczęto od zaprezentowania kontekstu historycznego oraz społecznego zjawiska, jak również przedstawienia niezbędnych definicji. Następnie przeanalizowano obowiązek zastosowania wobec gier komputerowych przepisów regulujących reklamę zawartych w najistotniejszych aktach prawnych. Wywody te uzupełniono rozważaniami na temat kwestii reklamowania wirtualnych produktów, które nie mają realnych odpowiedników. W dalszej kolejności przyjrzano się zjawisku możliwości dochodzenia przez reklamodawcę odszkodowania z tytułu wadliwej reklamy, jak również możliwości naruszenia dóbr osobistych twórców gry z powodu wprowadzenia do niej reklamy lub lokowania produktu przez wydawcę bez ich wiedzy i zgody.
\end{abstract}

Stowa kluczowe: gra komputerowa, reklama, lokowanie produktu, in-game advertising, advergaming 